\title{
The use of an anthropogenic structure by Eastern Red-backed Salamander (Plethodon cinereus)
}

\author{
DAVID L. LeGros
}

Algonquin Provincial Park, P.O. Box 219, Whitney, Ontario K0J 2M0 Canada; e-mail: david.legros@ontario.ca

LeGros, D.L. 2018. The use of an anthropogenic structure by Eastern Red-backed Salamander (Plethodon cinereus). Canadian Field-Naturalist 132(1): 58-60. https://doi.org/10.22621/cfn.v132i1.2019

\begin{abstract}
Eastern Red-backed Salamanders (Plethodon cinereus) are abundant in much of eastern North America. Although they typically live on the forest floor, individuals may venture off the ground while foraging. An adult salamander was observed using a backcountry privy as cover; after being displaced, it returned to the original location within $9 \mathrm{~h}$. Furthermore, the salamander scaled a $50-\mathrm{cm}$ vertical height to return to that location. The salamander may have been using the privy as part of its territory and feeding on flies attracted by the faecal matter inside.
\end{abstract}

Key words: Eastern Red-backed Salamander; Plethodon cinereus; homing; climbing; foraging; territoriality; Algonquin Provincial Park; Ontario

Lungless salamanders (Plethodontidae) are a diverse group of small forest- and stream-dwelling salamanders (Petranka 1998). Most species are strongly associated with forest floor habitats and cover, such as rocks and woody debris. Cover provides foraging opportunities and moist refuges that prevent evaporative water loss from the body (Spotila 1972; Jaeger 1980; Feder and Londos 1984).

Eastern Red-backed Salamander (Plethodon cinereus) is a common salamander in eastern North America and has been the subject of numerous ecological studies (reviewed by Petranka 1998 and Anthony and Pfingsten 2013). Jaeger et al. (1993) note its homing behaviour after being displaced, and many authors have documented its ability to climb (Jaeger 1978; reviewed in McEntire 2016). Here, I present an observation of a single Eastern Red-backed Salamander that used artificial cover, quickly returned to the location after being displaced, and climbed a vertical wooden surface to do so.

On the morning of 15 July 2017, I arrived on a small island in McCraney Lake, Algonquin Provincial Park, McCraney Township, Ontario $\left(45^{\circ} 33^{\prime} \mathrm{N}, 78^{\circ} 61^{\prime} \mathrm{W}\right)$ to camp for the night. The maximum daily air temperature was $26^{\circ} \mathrm{C}$ (minimum $14^{\circ} \mathrm{C}$, mean $20^{\circ} \mathrm{C}$ ). Of the 15 days leading up to the observation, precipitation fell on 10 days for a total of $55.6 \mathrm{~mm}$, recorded at the weather station located at the East Gate of Algonquin Provincial Park (near Whitney, Ontario), $50 \mathrm{~km}$ away (Environment Canada 2017). After inspecting the campsite, I proceeded to locate the privy, about $20 \mathrm{~m}$ away. At 1130 I lifted the lid and observed an adult Eastern Red-backed Salamander sheltering under the lid where the wood was in close contact with the seat. I moved the salamander to the forest floor, $1.5 \mathrm{~m}$ away. The following morning, at 0840, I returned to the privy to find that the salamander had returned to its exact original location.
The salamander was an adult, of the red-striped morph (Figure 1). I did not measure the snout-to-vent length or determine sex. I compared photos of the salamander from both days and used the pattern of small white head spots and markings on the tail to confirm that it was the same individual. Several slugs (Dusky Arion, Arion subfuscus/fuscus (Draparnaud, 1805)) and many flies were also found under the privy lid.

An Algonquin Provincial Park backcountry privy measures $82.5 \mathrm{~cm}$ (length) by $61 \mathrm{~cm}$ (width) by $51 \mathrm{~cm}$ (height), and has a hinged lid to allow the user to open and close it. The privy is constructed of Eastern White Cedar (Thuja occidentalis L.). Park maintenance crews inspect and repair privies regularly, and this unit was in good condition. No vegetation, sticks, or branches were touching the privy and, therefore, not aiding the salamander's climb.

Eastern Red-backed Salamanders have a relatively small home area, typically $0.16-0.33 \mathrm{~m}^{2}$ (Petranka 1998). In addition, they have a well-developed homing ability; when moved distances of $30 \mathrm{~m}$ most individuals are able to return, some even over distances of $90 \mathrm{~m}$ (Jaeger et al. 1993). Therefore, it is not surprising that the salamander was able to quickly (within $9 \mathrm{~h}$, and presumably less time, if activity is largely nocturnal) find its way back to its shelter; however, it also had to climb the vertical surface $(51 \mathrm{~cm})$ of the exterior of the privy.

Many lungless salamanders can make use of arboreal habitats and will climb vegetation and rock faces (McEntire 2016). Opportunistically, arboreal species, such as Eastern Red-backed Salamander, climb vegetation for several reasons. For example, Eastern Redbacked Salamanders that climbed vegetation had more food and larger prey items in their stomachs compared with those found foraging on the ground, suggesting

A contribution towards the cost of this publication has been provided by the Thomas Manning Memorial Fund of the Ottawa Field-Naturalists' Club. 


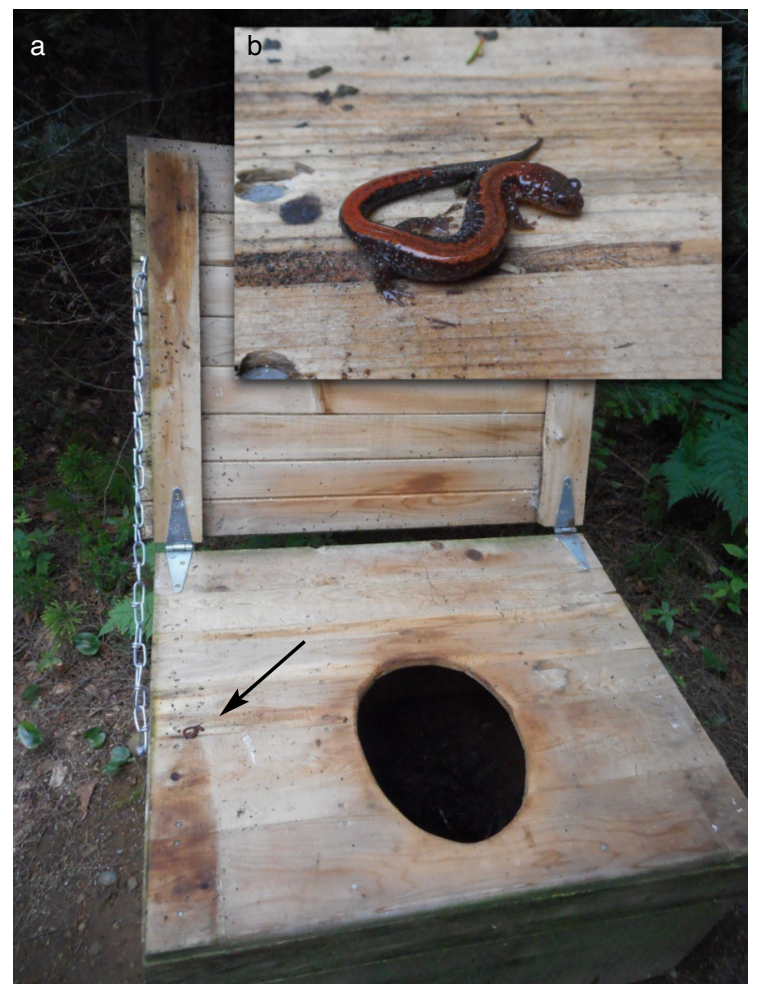

FIGURE 1. a. Algonquin Provincial Park backcountry privy with open lid. Note the Eastern Red-backed Salamander (Plethodon cinereus) found under the lid (arrow) returned to this location, after being moved the previous day. b. Close-up of $P$. cinereus as found. The salamander was taking cover under the lid and possibly feeding on the abundance of small flies. 15 July 2017 , Algonquin Provincial Park, Ontario. Photos: D. LeGros.

that climbing offers better foraging opportunities (Jaeger 1978). Salamanders may also climb vegetation to reduce predation risk or avoid dominant conspecifics on the ground (Roberts and Liebgold 2008). Although the extent of arboreal habitat use by temperate plethodontid salamanders is not well known, a growing body of work suggests that many species are using vertical habitats, such as plants, trees, and rock faces, more often than previously thought (McEntire 2016). Arboreal activity, like surface activity, in lungless salamanders is linked with wet conditions (LeGros 2013; McEntire 2016). Although the list of species and types of climbing continues to grow, little information is available regarding salamanders climbing human-made structures.

Adult Eastern Red-backed Salamanders are highly territorial and will aggressively defend territories from conspecifics to maintain access to quality food sources and mates (Jaeger 1982a; Jaeger and Forester 1993; Mathis et al. 1995; Petranka 1998). As the salamander in this observation was found under the privy lid during the day and quickly returned after being displaced, it likely included this cover as part of its territory (Mathis et al. 1995).
This observation is unique because the salamander established a territory $50 \mathrm{~cm}$ above ground, under artificial cover, which may have provided regular access to prey. An abundance of small flies emerged from the opened lid of the privy, most likely attracted to the human faecal matter contained inside. Although none of the flies was collected or identified, they were small and easily consumed by salamanders.

Dipterans are consumed by Eastern Red-backed Salamanders (Petranka 1998) and may make up as much as $10 \%$ of the diet of wild individuals (Jaeger unpubl. data, as cited in Jaeger and Barnard 1981). Eastern Red-backed Salamanders are capable of assessing prey quality and density and learn to forage optimally. In the laboratory, salamanders will use different foraging strategies when presented with low and high densities of two species of flies: for example, specializing in larger flies and ambushing them, rather than indiscriminately pursuing smaller flies (Jaeger and Barnard 1981; Jaeger et al. 1982b). Although it appears possible for Eastern Red-backed Salamanders to learn to take advantage of prey in high densities, they are not efficient patch foragers (Hill et al. 1982). Structurally simple environments with few obstacles and cover, such as the seat surface of the privy, improve the ability 
of the salamander to locate prey (Jaeger and Barnard 1981).

Although plethodontid diversity may be high in some regions of Appalachia, in central Ontario, Eastern Redbacked Salamander is the only representative of its genus (Petranka 1998). The lack of species diversity may allow this salamander the opportunity to expand its ecological niche in this region. In addition, the presence of privies throughout Algonquin and other provincial parks that offer backcountry camping opportunities may serve as an unintentional resource that concentrates invertebrate prey that feed on randomly distributed resources like dung. There are approximately 1900 similar privies located throughout Algonquin Provincial Park. According to several backcountry staff, who have checked thousands of privies over a span of many years, none has ever noted a salamander under the lid (three Algonquin Provincial Park staff members pers. comm. 11 November 2017). Although Eastern Red-backed Salamanders will defend a territory to access prey and mates, if the cover object is disturbed frequently, they may abandon the territory (Marsh and Goicochea 2003); thus, it is likely that salamanders do not occupy privies at regularly used campsites. Despite the lack of observations, privies could be a significant source of concentrated foraging opportunities for salamanders and other predators of insects.

\section{Acknowledgements}

I thank several Algonquin Provincial Park staff for assistance regarding information about backcountry privies. Special thanks to Patrick D. Moldowan and Peter B. Mills for their comments on earlier versions of this note. Thanks to Cortney LeGros for assistance in the field and campsite. I also thank the anonymous reviewers for their careful and constructive review of this note.

\section{Literature Cited}

Anthony C.D., and R.A. Pfingsten. 2013. Eastern RedBacked Salamander, Plethodon cinereus. Pages 335-360 in Amphibians of Ohio. Edited by R.A. Pfingsten, J.G. Davis, T.O. Matson, G. Lipps, Jr., D. Wynn, and B.J. Armitage. Bulletin XVII(1) new series. Ohio Biological Survey, Columbus, Ohio, USA.

Environment Canada. 2017. Hourly data report for 15 July 2017: Algonquin Park East Gate, Ontario. Environment Canada, Ottawa, Ontario, Canada. Accessed 11 November 2017. https://tinyurl.com/y8eku88r.

Feder, M.E., and P.L. Londos. 1984. Hydric constraints upon foraging in a terrestrial salamander, Desmognathus ochrophaeus (Amphibia: Plethodontidae). Oecologia 64: 413418. https://doi.org/10.1007/BF00379141
Hill, J., D.R. Formanowicz, and R.G. Jaeger. 1982. Patch foraging by a terrestrial salamander. Journal of Herpetology 16: 405-408. https://doi.org/10.2307/1563572

Jaeger, R.G. 1978. Plant climbing by salamanders: periodic availability of plant-dwelling prey. Copeia 1978: 686-691. https://doi.org/10.2307/1443697

Jaeger, R.G. 1980. Microhabitats of a terrestrial salamander. Copeia 1980: 265-268. https://doi.org/10.2307/1444003

Jaeger, R.G., and D.E. Barnard. 1981. Foraging tactics of a terrestrial salamander: choice of diet in structurally simple environments. American Midland Naturalist 1981: 639664. https://doi.org/10.1086/283750

Jaeger, R.G., D.E. Barnard, and R.G. Joseph. 1982b. Foraging tactics of a terrestrial salamander: assessing prey density. American Naturalist 119: 885-890. https://doi.org/10. $1086 / 283964$

Jaeger, R.G., and D.C. Forester. 1993. Social behavior of Plethodontid salamanders. Herpetologica 49:163-175.

Jaeger, R.G., G. Fortune, G. Hill, A. Palen, and G. Risher. 1993. Salamander homing behavior and territorial pheromones: alternative hypotheses. Journal of Herpetology 27 : 236-239. https://doi.org/10.2307/1564945

Jaeger, R.G., D. Kalvarsky, and N. Shimizu. 1982a. Territorial behavior of the red-backed salamander: expulsion of intruders. Animal Behaviour 31: 490-496. https://doi.org/ 10.1016/S0003-3472(82)80061-4

LeGros, D.L. 2013. Plant climbing in the Northern Two-lined Salamander, Eurycea bislineata, in Algonquin Provincial Park, Ontario. Canadian Field-Naturalist 127: 67-69. https: //doi.org/10.22621/cfn.v127i1.1411

Mathis, A., R.G. Jaeger, W.H. Keen, P.K. Ducey, S.C. Walls, and B.W. Buchanan. 1995. Aggression and territoriality by salamanders and a comparison with the territorial behavior of frogs. Pages 633-676 in Amphibian Biology, Volume 2, Social Behaviour. Edited by $\mathrm{H}$. Heatwole and B.K. Sullivan. Surrey Beatty and Sons, Chipping Norton, New South Wales, Australia.

Marsh, D., and M. Goicochea. 2003. Monitoring terrestrial salamanders: biases caused by intense sampling and choice of cover object. Journal of Herpetology 37: 460-466. https: //doi.org/10.1670/98-02A

McEntire, K.D. 2016. Arboreal ecology of Plethodontidae: a review. Copeia 2016: 124-131. https://doi.org/10.1643/OT$14-214$

Petranka, J.W. 1998. Salamanders of the United States and Canada. Smithsonian Institution Press, Washington, DC, USA.

Roberts, A.M., and E.B. Liebgold. 2008. The effects of perceived mortality risk on habitat selection in a terrestrial salamander. Behavioral Ecology 19: 621-626. https://doi. org/10.1093/beheco/arn012

Spotila, J.R. 1972. Role of temperature and water in the ecology of lungless salamanders. Ecological Monographs 49: 95-125. https://doi.org/10.2307/1942232

Received 22 November 2017

Accepted 4 February 2018 